\title{
West Region's Financial Efficiency and Economic Growth
}

\author{
Cong Liu \\ International Business School, Shaanxi Normal University \\ Xi'an, China \\ 396800247@qq.com
}

\begin{abstract}
The effects that financial development have on economic growth has been hottly debated in the economic community. In China, the western regions are known as less developed regions. The western regions, greatly promoted by the western development strategy, still lagging behind compared with the central and eastern China. Therefore, solutions should be found to achieve balanced development. Finance plays a vital role in the economic system, so it is easy for us to figure out the economic growth in the western region has become an inevitable trend from a financial perspective. In this paper, the author tries to explore a better economic growth mode of economic development for the balanced development in China.
\end{abstract}

Keywords-Financial development; Economic growth; Financial related rate

\section{INTRODUCTION}

The earliest suggestion to unlock the mystery of the relationship between financial development and economic growth is in the 1960s, all the world's economists have contributed their own strength to it. The theory has attracted the attention of scholars from all over the world. They have not only carried out qualitative research, but also established a theoretical model and quantitative analysis and verification. Such as Patrick, Ronald McKinnon are made fruitful research contributions, the beginning is limited to the preliminary exploration, a simple model, which lack of data collection tools, so the conclusion is only simple relationship between the financial and economic. With the progress of science and technology and the access to knowledge, people have deeply explored the relationship between them, and the theoretical demonstration has made great achievements. The relationship between different countries and regions is significantly different. But international studies are more about developed countries but little research on China, even developed western area in China.

In order to realize the great Chinese dream and achieve a well-off society by 2020 , we should improve the economic level of the backward areas in order to achieve balanced development of the whole country. In the western region, most of the provinces, autonomous regions and municipalities directly under the central government's economy is not developed, while in the western development strategy, there have been some improvement, but compared to the east, it's far away from that. Therefore, we should understand the financial and economic impact and find effective measures to improve the economic level of the western region. This paper not only analyzes the impact of financial development on economic growth from the theoretical level, but also the data. And give some corresponding Suggestions. In this paper, the selected data is from the national statistical official website and regional financial operation report, accurate, scientific.

\section{A REVIEW OF FINANCIAL DEVELOPMENT AND ECONOMIC GROWTH}

The concept of financial development was first introduced in 1969, and goldsmith (1990) [1] believed that it was a tool plus structure, which meant that the two were updated and changed. Foreign scholars dedicated all of the research to the developed countries, until McKinnon (1990) and shaw (1988) [2], they turned to the Angle of developing countries, and explains the relationship between the two into a system, to analyze their depression is out of the financial sector is underdeveloped, McKinnon blamed the financial distortions on the financial structure, and Shaw put the blame on government intervention. In the 1990s, Pagano (1993) [3] broke through the old ideas from the perspective of internal analysis and influence mechanism. (1) Saving investment conversion rate (2) effective allocation of resources (3) increase the social saving rate. In order to achieve better financial development, Greenwood and Jovanovic (1991) [4] felt that financial intermediaries were crucial, linking economic organizations to a whole, information flows quickly and better to promote economic growth. King and Levine (1993) [5] conducted a quantitative analysis, collected data, defined the financial indicators, and mining two relations deeply. They found that there is a role between them through the study, and this can even predictions of economic growth.

Tan yongru (1999) [6] use the method of correlation coefficient in the economic development of financial development, the influence of financial intermediary and stock market on the economy was studied. It is found that the former is positively correlated with economic growth, while the latter is negatively correlated. Kong dongmin (2007) [7] first proposed to use the threshold model to study the non-linear relationship between two factors, with the inflation rate as the threshold variable. It shows that the correlation coefficient between financial development and economic growth is large when the inflation rate is $3.9 \%$ (or $6.5 \%$ ). Li yue (2014) [8] 
using the stochastic coefficient model and the qualification of inflation based on the relevant panel data from 1979 to 2012 in 31 provinces. She gave a different range of inflation. When less than $0.9 \%$, when financial development, the economy will have some regression, greater than $0.9 \%$, the economy will grow as the financial development. The higher the value, the stronger the effecting.

In order to eliminate the influence of population factors, Wang wensheng and Chai yongdong (2010) [9] measured the economic development level of each region from 1999 to 2007 in the eastern region, the western region and the central region from 1999 to 2007, taking the financial development of the three regions in 1999-2007 as an indicator of the level of financial development, the empirical model was verified and concluded that such influence exists. However, the effects of the various regions in our country are different. The western region is more serious. Liu Xiaobin and Wu yan (2014) [10] explained the financial development as a variable, taking economic development as the explained variable, the investment and labour as control variable, and used the data of the nine provinces of the western region from 1990-2012, carried on the quantitative research.
In conclusion, exploring the influence of financial development on economic growth in the west plays a key role in developing the west.

\section{THE PRESENT SITUATION OF FINANCIAL DEVELOPMENT AND ECONOMIC GROWTH IN WESTERN CHINA.}

The western part of China is not a developed area of our country. Although the area is quite vast, the population density is relatively sparse. The ethnic minorities in the west are concentrated and rich in resources.

From the perspective of financial structure, first of all, the western financial system is still dominated by Banks. The number of Banks in the western region is quite different from that in the east, and the number of banking institutions in the western 12 provinces is quite different. The Sichuan province has the maximum number of institutions in 13751, and the Tibet autonomous region is only 677, 5\% less than Sichuan province, compared with the difference of employed workers is greater, Tibet is $3 \%$ less than Sichuan.

TABLE I. THE SITUATION OF BANKING FINANCIAL INSTITUTIONS IN WESTERN CHINA IN 2016

\begin{tabular}{|c|c|c|c|c|c|c|c|c|c|c|c|c|c|}
\hline provinces & Chongqing & Sichuan & Guizhou & Yunnan & Guangxi & Shaanxi & Gansu & Qighai & Ningxia & Tibet & Xinjiang & $\begin{array}{c}\text { Inner } \\
\text { Mongolia }\end{array}$ & Total \\
\hline $\begin{array}{l}\text { number of } \\
\text { institutions }\end{array}$ & 5439 & 13751 & 4852 & 5481 & 5984 & 6749 & 4670 & 1111 & 1233 & 677 & 3604 & 4683 & 58234 \\
\hline $\begin{array}{l}\text { number of } \\
\text { employees }\end{array}$ & 68756 & 225745 & 64945 & 75633 & 91282 & 96798 & 61423 & 17230 & 22103 & 8427 & 58567 & 94259 & 885168 \\
\hline
\end{tabular}

In our country, there are many types commercial Banks, and in the western region, arge joint-stock Banks almost monopoly, and the business amount is big, and lack of the small one, the small one are only in some provinces but little large city, other cities in the province has less types of bank Foreign Banks are even scarcer in western. In 2016, there were 1,008 Banks with foreign investment in China, 80 more than in 2015. Total assets were 2.7 trillion yuan, increased 8

percent year on year. In the middle and eastern regions, the two countries accounted for 83.2 percent and 93.1 percent of the total. Although there is no specific data on the proportion of foreign banks in the western region. The Middle and the East have occupied the most of it. There is little for western. Such distribution is not good for the effect decomposition of risk, and result in the financial unhealthy operation.

TABLE II. REGIONAL DISTRIBUTION OF BANKING FINANCIAL INSTITUTIONS AT THE END OF 2016 , PER UNIT \%.

\begin{tabular}{c|c|c|c|c}
\hline & $\begin{array}{c}\text { The proportion of legal } \\
\text { entities }\end{array}$ & Organization ratio & $\begin{array}{c}\text { The proportion of people } \\
\text { employed }\end{array}$ & $\begin{array}{c}\text { The proportion of total amount } \\
\text { of assets }\end{array}$ \\
\hline eastern & 41 & 45.2 & 58.4 & 37.2 \\
\hline central & 22.7 & 20.3 & 15.3 & 23.9 \\
\hline Western & 26.8 & 23.8 & 19.3 & 30.2 \\
\hline total & 100 & 100 & 100 & 100 \\
\hline
\end{tabular}

As we can see from the table, there is a large gap between the western region and the eastern region. This is not in line with the size of the west and the population.

Capital market: In China, the development of capital market is not balanced. The east is developed, while the west is backward.
Financial scale: The financial development in the western region is far less than that of the eastern region. On the scale of quantitative finance development, Goldsmith proposed five indicators, but the most widely used is the financial correlation rate. 
TABLE III. FINANCIAL CORRELATION RATE OF EASTERN, CENTRAL, WESTERN AND NORTHEAST REGION IN 2016, UNIT: TRILLION.

\begin{tabular}{c|c|c|c|c}
\hline area & $\begin{array}{c}\text { The balance of all deposits in } \\
\text { RMB and Forex }\end{array}$ & $\begin{array}{c}\text { The balance of loans in } \\
\text { RMB and Forex }\end{array}$ & GDP & FIR \\
\hline eastern & 65.4 & 47.1 & 35 & 3.2 \\
\hline central & 18.8 & 12.9 & 13.9 & 2.3 \\
\hline western & 22.3 & 17 & 13.8 & 2.8 \\
\hline northeast & 7.8 & 6 & 5.7 & 2.4 \\
\hline
\end{tabular}

As we can see from the table, the financial correlation rate in the western region is lower than that in the eastern region. Therefore, the financial scale of China's western region is not as good as that of the eastern region.

The Current situation of economic development in western region:

TABLE IV. Per CAPITAL DISPOSABLE INCOME OF URBAN RESIDENTS IN EACH REGION IN 2014, UNIT: YUAN, \%.

\begin{tabular}{c|c|c|c|c}
\hline area & $\begin{array}{c}\text { Disposable income of urban } \\
\text { residents }\end{array}$ & $\begin{array}{c}\text { Weighted average growth } \\
\text { rate }\end{array}$ & $\begin{array}{c}\text { Disposable income of rural } \\
\text { residents }\end{array}$ & $\begin{array}{c}\text { Weighted average growth } \\
\text { rate }\end{array}$ \\
\hline eastern & 36471 & 8.9 & 15826.7 & 10.8 \\
\hline central & 24753.3 & 9.1 & 9989 & 11.5 \\
\hline western & 23977.4 & 9 & 8286.2 & 11.7 \\
\hline northeast & 25310.6 & 8.8 & 10816.7 & 10.6 \\
\hline
\end{tabular}

As we can see from the table, in the western region, whether the people in the city can spend money or the residents in the village are lower than the eastern region.

TABLE V. REGIONAL DISTRIBUTION OF THE THREE INDUSTRIES IN 2014 IN EACH REGION, UNIT: $\%$.

\begin{tabular}{c|c|c|c|c|c}
\hline & eastern & central & weastern & northeast & total \\
\hline The first industry & 34.5 & 26.3 & 28.2 & 11 & 100 \\
\hline The second industry & 49.5 & 21.5 & 20.5 & 100 & 7.4 \\
\hline The third industry & 56.1 & 17.8 & 18.3 & 100 \\
\hline
\end{tabular}

As we can see from the table, the production structure of the western region mainly focuses on one or two industries, while the eastern region has a larger proportion of three industries.

\section{THEORETICAL ANALYSIS OF THE IMPACT OF FINANCIAL DEVELOPMENT ON ECONOMIC GROWTH.}

(1)The concept of financial development is not invariable. The concept of financial development changes with the development of national economy. The whole process is dynamic and continuously optimized. In the narrow sense, the measure of financial development is the total amount of finance, which is a measure of pure quantity, and one-sided and even unscientific. The broad financial development is not limited to the measurement of quantity, but more comprehensive and objective from the various elements of financial development. Financial related rate (FIR) is a good quantitative values, within the scope of a certain period of time, a country or a region of bank deposits and loans than on the time of the region or the country's gross domestic product, the bigger the greater the Financial development.
Income level: If the economic growth is only reflected in GDP, it is one-sided and depends on the income level of residents. Economic growth is bound to bring high income level. pursue a big number, but the reasonable structure. 
TABLE VI. FINANCIAL CORRELATION RATE OF EASTERN, WESTERN IN 2013 AND 2014.

\begin{tabular}{c|c|c|c|c|}
\hline area & \multicolumn{2}{|c|}{ eastern } & \multicolumn{2}{c}{ western } \\
\hline year & 2015 & 2016 & 2015 \\
\hline Total deposit and loan & 102.53 & 112.5 & 34.72 \\
\hline GDP & 32.2 & 35 & 12.6 \\
\hline FIR & 3.181 & 3.21 & 2.3 \\
\hline
\end{tabular}

We can make a longitudinal comparison from the above table, with the increase in the total amount of deposits and loans, GDP also increases with the increase. Similarly, there is a scientific measure of financial scale and financial relevance. At the same time, a horizontal comparison can be made. The total amount of deposits and loans in the eastern region is increased relative to the total amount of deposits and loans in the western region, we can see the GDP growth in the eastern region relative to the western region as well. So it can be seen that economic growth is being influenced by financial development.

\section{TO PROMOTE ECONOMIC AND FINANCIAL DEVELOPMENT IN THE WESTERN REGION}

The western region can use the "One Belt, One Road" and the silk road fund and other strategic opportunities to deepen the reform of the financial system and speed up the construction of the local financial system. And increase the variety of financial products in various forms, enhance services and provide diversified services for residents. For the financing guarantee, we should make the system as possible as we can, and compensate the residents for the risks, so as to make the residents safe and comfortable. Reform cannot be lax, for border city, speed up the pace of reform and refreshed the yuan to the two-way flow, through the policies and measures to make financial market environment scientific rationalization, avoid the potential risk.

(1) Expand the amount of the western region. The eastern part of the financial scale have been to the western region is far behind from the above data analysis, high financial scale is will lead to the development of economy, achieve economies of scale for the enterprise to provide the possibility. Therefore, the western region should strive to increase the total amount of finance and expand its scale.

(2) Optimize the financial structure of the western region. The financial system in the western region is relatively unitary, which is bound to restrain the development of the financial industry. The development of financial institutions should be diversified and the functions of policy-based Banks should be promoted, so that they can raise a large amount of funds through certain measures and provide financial support for economic development. The western region should enhance the diversification of financial system, learn advanced ideas, promote regional bank competition, and form a good financial market.

(3) Increase capital input. The development level of financial industry in western region is low, so the development of financial market should be taken seriously. Developing the securities industry and insurance industry vigorously.

\section{REFERENCES}

[1] RaymondW, Goldsmith. Financial structure and financial development [M]. Trans. Zhou shuo et al. Shanghai: Shanghai sanlian bookstore, 1990

[2] EdwardS, Shaw. Financial deepening in economic development [M]. Shao fujun et al. Shanghai: Shanghai sanlian bookstore, 1988

[3] Pagano, Marco. Financial Markets and Growth: An Overview [J]. European Economic Review. 1993,37(2-3): 613-622

[4] Greenwood, Jeremy and Jovanvic, Boyan. Financial Development Growth and the Distribution of Income. Journal of Political Economy, 1990, 98(5): 1076-1107

[5] King, Robert G.and Levine, Ross. Capital Market and Financial Intermediation [M].New York: Cambridge University Press, 1993:156196

[6] Tan yongru, the relationship between Chinese financial development and economic growth [J]. Economic research, 1999, (10):53-61.

[7] Kong dongmin. Is inflation impeding financial development and economic growth? A new test based on a threshold regression model [J]. Quantitative economic and technical economic research, 2007(10):56-66.

[8] li yue. Research on the relationship between China's financial development and economic growth [D]. Changchun: jilin university, 2014

[9] Wang wensheng, wood building. Western financial development and regional economic disparity -- empirical analysis based on panel data $[\mathrm{J}]$ Financial BBS, 2010, (10):43-47.

[10] Liu xiaobin, wu yan. Discussion on the relationship between financial development and economic growth in underdeveloped regions -- based on the panel data analysis of the nine provinces of western China [J]. Western finance, 2014, (09):71-75. 